\title{
Perception of social responsibility and banking activities in Puerto Rico
}

Juma'h, Ahmad H.

Morales-Rodríguez, Doris

- ReCeived: 28 february 2015

- ACCEPTED: 25 MaY 2015

\section{Abstract}

The purpose of this article is to explore the perceptions that economics and psychology professionals have of banking activities with respect to social responsibility. Data were collected by means of a survey, and descriptive and inferential statistics were then used to present and analyze the data. The results indicate that a majority of participants in both groups (psychology and economics) do not perceive the banks' activities as essential to Puerto Rico's social and economic development. Most participants agree that financial cooperative institutions are better than banks in terms of providing access to sources of finance.

\section{Keywords:}

Banking activities, Financial difficulties, Social responsibility.

\section{JEL classification:}

E44, G01, G21, N26, M14. 


\title{
Responsabilidad social y actividades bancarias: percepción en Puerto Rico
}

\author{
Juma'h, Ahmad H.
}

Morales-Rodríguez, Doris

\section{Resumen}

El objetivo de este artículo es explorar la percepción de los profesionales de la Economía y la Psicología acerca de la responsabilidad social en las actividades bancarias. La información utilizada proviene de una encuesta realizada a tal fin, habiéndose utilizado tanto las técnicas estadísticas descriptivas e inferenciales para presentar y analizar los datos, respectivamente. Los resultados indican que la mayor parte de los participantes en ambos grupos (Psicología y Economía) no perciben que las actividades bancarias sean esenciales para el desarrollo económico y social de Puerto Rico. La mayoría está de acuerdo en que las instituciones financieras de carácter cooperativo superan a los bancos en lo que a la provisión de fuentes de financiación se refiere.

\section{Palabras clave:}

Actividades bancarias, dificultades financieras, responsabilidad social. 


\section{Introduction}

Most companies, particularly financial institutions, were affected by the financial crisis that began in 2008. The Federal Reserve Bank (Fed) in the United States has intervened in the functioning of the banking industry several times in order to prevent the collapse of the system ${ }^{1}$. Furthermore, the effects of the measures taken by the United States federal government to minimize the economic crisis did not fulfill the economists' target objectives. The financial crisis which began in 2008 is considered by some as one of the most severe since the Great Depression of 1929.

During the period 2005-2015, Puerto Rico's economy has been characterized by a high unemployment rate ( $12.5 \%$ average), a low labor participation rate $(40 \%$ average) and a low employment rate (35\% average). The country has also experienced a sustained decline in real GDP at an annual average rate of $-3 \%$, driven by the fall in the real cost of construction investment, the fall in real investment in machinery and equipment, relocation of multinational enterprises, and the government policy of spending cuts. This was exacerbated following the burst of the housing bubble and the banking crisis. Furthermore, the country is facing a severe fiscal crisis and the degradation of public debt amounted to $\$ 73$ billion in 2015; in addition to this, there has been a reduction of the financial system (Juma'h et al., 2015; Marxuach, 2012; Benson, 2011).

The financial crisis led some Puerto Rican banks to consolidate their activities. Banking executives point out that further consolidation will be beneficial in the long term by making the market more attractive and enabling the banks to earn a return on adequate capital. The industry now faces a new challenge of how it can continue to grow and to contribute to the economic growth and development of Puerto Rico. The banking crisis in Puerto Rico reached its climax on April 30, 2010 with the banking consolidation carried out via the Loss Sharing Transaction by the FDIC ${ }^{2}$, entailing the acquisition of 3 three institutions: RG Premier Bank, Westernbank and Eurobank. The Puerto Rican Government pointed out that the situation was caused mainly by (1) the weak economic environment and depreciated Real Estate market, (2) errors in borrowing strategies in which the Board of Directors and management staff failed to provide effective measures to deal with an economy that was deteri-

\footnotetext{
${ }^{1}$ Federal law and US policies govern international relations, migration, customs and national security, and also regulate communications, the labor market, as well as the monetary and banking system in Puerto Rico. Similarly, the economy of the Island and the United States are linked under the Federal Relations Act of Puerto Rico, also known as the Jones Act.

2 Federal Deposit Insurance Corporation (FDIC) preserves and promotes public confidence in the US financial system by insuring deposits in banks. To protect insured depositors, FDIC responds when a bank or thrift institution fails, and it also sells or obtains the bank's assets to pay off the debts. In the Loss Sharing Transaction, FDIC acquired three banks to then sell to a third institution and reimbursed up to 80 percent of the losses incurred by the purchaser of the assets, with the remaining 20 percent absorbed by the buyer (Planning Board of Puerto Rico, 2010).
} 
orating, (3) insufficient subscriptions and diversification of loans that caused impairment of assets and capital, increased risk and low profits, (4) lack of preventive practices to monitoring high risk loans and low credit, and (5) inadequate amount of liquidity and capital caused by deteriorating earnings and the inability to acquire additional capital (Planning Board of Puerto Rico, 2010).

It is believed that financial institutions should be part of the solution to this financial problem. Banks contribute to financing economic activity in the public and private sectors, however, their interests may differ from the public factors that contribute to economic growth. Accordingly, banks sometimes adopt social responsibility strategies to influence public perception of banks' behavior.

Therefore, the perception of professionals in the fields of economics and psychology can be key to exploring the importance of banking activities in relation to social responsibility, which constitutes the main objective of this article. These professional groups are assumed to be more knowledgeable on these issues.

The article is organized into the following sections: the next section presents aspects related to the concept of social responsibility and banking activities; the third section identifies the methodology used; the fourth section describes the data collected in the survey; and the final section presents the summary and conclusions.

\section{Social responsibility and banking activities}

Banking activity is directly associated with the growth and the economic development of countries. Through the banking system, capital is made available to finance the development of new technologies in business and economics (Harper and Chan, 2003).

Governments around the world play a significant role with regards to banking activities in their countries. It is argued that the less developed countries usually have a government system that does not adequately protect private property, a situation which is associated with lower per capita income. Minimal regulation of banking activities is associated with the capitalist market economy (Wray, 2012; La Porta et al., 2002; Barth et al., 2001, 2004).

Minimal financial regulation usually results in many undesirable practices such as tax evasion, money laundering and the use of inside information for profit, which are difficult to detect and may be associated with crisis in the financial markets. However, the financial flexibility associated with minimal regulation of financial institutions allows companies to deal with uncertainty that could affect the cash flow 
and the determination of the capital structure. The illegal actions of financial managers are difficult to detect precisely because the institution may manipulate accounting information in order to mislead users (Gobert and Punch, 2003; Orland, 1995; Gibbs and Simpson, 2007; Levi, 1987; Tomasic, 2000, 2005).

In Puerto Rico, the banks investigated by the Securities and Exchange Commission (SEC) had the following issues: weak management of credit risk, in particular in the construction industry; excessive use of brokered deposits; deficient credit analysis; inadequate capital reserve; and disregarding suggestions or requirements of regulatory agencies (Planning Board of Puerto Rico, 2010).

Society's perspective of the company has evolved; over time it has become an important social agent whose contribution to the collective well-being is ensured through ethical criteria a new concept within the company as an integrated socioeconomic unit. The reason for this transformation is based on the assumption that the State cannot fully take on the social function. This motivated a group of business executives to voluntarily undertake the task of beginning to adopt paternalistic behaviors which were incorporated in their companies as part of their socio-economic model (Truño, 2006; Elias, 2004; Guang et al., 2006; Niu, 2006).

Corporate social responsibility forms part of a new business concept, according to which the company is not designed solely to generate profit, but has the additional objective of meeting society's needs. Kohers and Simpson (2002) argue that corporate social responsibility improves the financial performance of the company. Maignan (2001) specifies that this improved financial performance is due to the significant increase in sales, produced by greater customer loyalty. Surroca et al. (2010) state that corporate social responsibility stimulates the development of intangible resources such as innovation, human capital, culture and reputation, which in turn improve financial performance.

In the same vein, Smith (2003) points out that it is common practice within companies to reevaluate their image and reputation in terms of social responsibility. In addition, other researchers refer to the increased ability to attract and retain employees as a benefit of corporate social responsibility, or the increased access to capital that socially responsible companies have earned (Hockerts and Moir, 2004).

There is no one agreed definition of corporate social responsibility, but most definitions suggest that it is a business strategy which aims to improve countries' social, economic and natural environment. Academics and practitioners, however, view these strategies differently and the limited empirical research is descriptive (Mohr et al., 2001). The positive relationship between corporate social responsibility and 
customer satisfaction has been partially supported by empirical research (Argenti et al., 2005).

Corporate social responsibility is considered an essential element of business marketing strategies. Since the financial crisis, social responsibility has become even more relevant in the banking sector. The concept is associated with specific aspects of the banking sector such as materiality, risk and moral hazard. Banks use social responsibility in the formulation of their policy and management and with respect to consumer relations (Burioanova and Paulik, 2014; Yeung, 2011 Pirch et al., 2007), and they try to communicate their social responsibility to the community in various ways (Gore, 1988; Peterson and Hermans, 2004). Despite this, some bank customers' perception is that the banking sector does not adequately exercise their social responsibility.

Some companies aim to keep certain specific groups satisfied when competition intensifies. In such a situation, the contributions related to corporate social responsibility could influence customers (Yeung, 2011; Lewis and Soureli, 2006; Bejou et al., 1998). A number of studies investigate the interdependence of customer expectations towards corporate social responsibility and their perception of quality (Garcia Salmon et al., 2005; Brown and Dacin, 1997).

In addition, managers become more confident in their companies after initiating corporate social responsibility programs aimed at establishing internal factors such as monitoring and supervision as well as external factors such as trust and loyalty generated by activities related to corporate social responsibility. In industries that rely on banks for their operations, customers perceived quality as a function of trust (Lewis and Soureli, 2006).

From the websites of the main banks in Puerto Rico (see Table 1), we found that the banking institutions in Puerto Rico have corporate social responsibility policies focused on a range of elements contributing to economic and social development. The main Island bank, Popular Bank of Puerto Rico, which is the largest in terms of deposits, assets and branches, has a more comprehensive, diverse corporate social responsibility policy.

These policies focus mainly on areas such as education, art, culture, sports, environment, health, entrepreneurship, financial education and promoting personal savings. They can be further classified into three types: philanthropic policies, which center on fundraising or providing financial donations to specific causes; awareness policies, which are those that identify problematic issues in society and try to draw citizens' attention to such issues and encourage them to take action accordingly; 
and volunteering policies, involving banking staff dedicating their time and effort on behalf of a particular purpose.

Table 1. Examples of social responsibility corporate policies for banks operating in Puerto Rico

\begin{tabular}{|c|c|c|c|}
\hline Bank & Foundation & Origin & Social responsibility corporate policies areas \\
\hline $\begin{array}{l}\text { Banco Popular } \\
\text { de Puerto Rico }\end{array}$ & 1893 & Puerto Rico & $\begin{array}{l}\text { 1. Financial Education / 2. Sports / 3. Music / 4. Arts / 5. Education / } \\
\text { 6. Support to community service programs / 7. Voluntary work / } \\
\text { 8. Sponsorship and fundraising for different causes. }\end{array}$ \\
\hline $\begin{array}{l}\text { Banco } \\
\text { Santander de } \\
\text { Puerto Rico }\end{array}$ & 1976 & Spain & $\begin{array}{l}\text { 1. Post-Secondary Education / 2. Sports / 3. Environmental } \\
\text { Conservation / 4. Promoting Puerto Rico as business destination. }\end{array}$ \\
\hline Oriental Bank & 1964 & Puerto Rico & 1. Supporting education in business administration areas. \\
\hline Doral Bank* & 1972 & Puerto Rico & $\begin{array}{l}\text { 1. Fundraising and donations to different causes / 2. Education } \\
\text { and donations for female entrepreneurship / 3. Enviromental } \\
\text { Conservation / 4. Art and Cultural donations / } 5 \text {. Raising funds and } \\
\text { awareness for cancer / } 6 \text {. Education for promoting personal savings } \\
\text { / 7. Supporting microenterprise. }\end{array}$ \\
\hline Scotia Bank & 1910 & Canada & 1. Fundraising and donations to different causes. \\
\hline
\end{tabular}

SOURCE OF DATA:WWW.SANTANDER.COM;WWW.DORALBANK.COM;WWW.SCOTIABANK.COM; WWW.ORIENTALBANK.COM;WWW.BANCOPOPULAR.COM; EXTRACTED ON AUGUST 20, 2014.

* IN FEBRUary 27, 2015 ThIS bank CEASED operations.

MOST OF ITS ACTIVITIES WERE ACQUIRED BY BANCO POPULAR DE PUERTO RICO.

\section{Data and methods}

The data used in this article are part of a survey (see Appendix) distributed to members of graduate and professional schools in the Metropolitan Campus of the Inter American University of Puerto Rico during the year 2012. From 110 surveys, we received 91 completed ones. Selected data used in this article come from survey participants in the School of Economics and the School of Psychology. This study focuses on professionals in economic and administrative sciences since it is assumed that they have a greater understanding of the economic situations that many developing countries have been facing since 2008. Participants' responses from the School of Psychology are used for purposes of comparison in relation to the issue of social responsibility.

The survey includes both closed questions (on a scale of one to five) and open questions. It is divided into three sections: Section A covers the demographics of the participants; Section B explores participants' perception of the importance of banking activities in the social field and addresses the relationship between banking and meeting the needs of society; and Section $C$ describes the relationship between current activities with respect to interest rates and other forms of banking. 
For validation purposes, five professors from each school validated the content of the survey in its entirety. The methodology used to analyze the data obtained with the instrument includes descriptive statistics (mean, variance, and standard deviation) and the two sample $t$-tests for comparing the means of two groups.

\section{Results}

Table 2 shows the distribution of gender in each school (Economics and Psychology). The total sample was divided into $56 \%$ female and $44 \%$ male. The total number of responses incorporated 51 from the School of Economics and 40 from the School of Psychology.

\section{Table 2. The gender distribution in the sample}

\begin{tabular}{lccc}
\hline Gender & Female & Male & Total \\
\hline Classification & Number (\%) & Number (\%) & \\
\hline Economics & $22(44 \%)$ & $29(56 \%)$ & 51 \\
\hline Psychology & $28(70 \%)$ & $12(30 \%)$ & 40 \\
\hline Total & $50(56 \%)$ & $41(44 \%)$ & 91 \\
\hline
\end{tabular}

It can be seen from Table 3 that the average participants' perception of the contribution made by banking activities to economic growth in Puerto Rico is 3.0 and 3.27 in the groups of economics and psychology, respectively, on a scale of 1-5; and the $t$-test of the averages does not show statistical significance $(\alpha=0.10)$. The average perception of participants regarding the contribution made by the banks in order to meet citizens' need to obtain residences with low interest is 2.5 and 2.7 in the group of economics and psychology, respectively; and the $t$-test of averages does not show statistical significance $(\alpha=0.10)$.

The average perception of participants regarding making sources of finance available to entrepreneurs, and small and medium-sized enterprises (SMEs) is 2.4 and 2.8 in the groups of economics and psychology, respectively; and the $t$-test for independent means shows statistical significance $(\alpha=0.10)$. The average perception of participants regarding support to charities on the island is 3.5 and 2.78 in the groups of economics and psychology, respectively; and the $t$-test for independent means shows statistical significance ( $\alpha=0.05$ ). The average perception of the participants regarding the proper use of natural resources and the environment is 3.4 and 2.8 in the groups of economics and psychology, respectively; and the $t$-test shows statistical significance $(\alpha=0.10)$. 
Table 3. Participants' perceptions of banking activities

\begin{tabular}{|c|c|c|c|c|c|c|c|}
\hline \multirow{2}{*}{$\begin{array}{l}\text { Classification } \\
\text { The level of bank compliance } \\
\text { with respect to: }\end{array}$} & \multicolumn{3}{|c|}{ Economics } & \multicolumn{3}{|c|}{ Psychology } & \multirow[b]{2}{*}{$t$-test } \\
\hline & $T$ & Mean & $\begin{array}{l}\text { Standard } \\
\text { Deviation }\end{array}$ & $T$ & Mean & $\begin{array}{l}\text { Standard } \\
\text { Deviation }\end{array}$ & \\
\hline $\begin{array}{l}\text { Contribution to the economic } \\
\text { growth of the Island }\end{array}$ & 51 & 3 & 1.31 & 40 & 3.27 & 1.3 & -0.97 \\
\hline $\begin{array}{l}\text { Contribution to meeting } \\
\text { citizens' needs to obtain } \\
\text { residences with low interest }\end{array}$ & 51 & 2.5 & 1.07 & 40 & 2.73 & 1.27 & -.95 \\
\hline $\begin{array}{l}\text { Making sources of finance } \\
\text { available to entrepreneurs } \\
\text { and SMEs }\end{array}$ & 51 & 2.4 & 1.14 & 38 & 2.84 & 1.18 & $\begin{array}{c}-1.69^{\star} \\
(.09)\end{array}$ \\
\hline $\begin{array}{l}\text { The proper use of natural } \\
\text { resources and the } \\
\text { environment }\end{array}$ & 51 & 3.42 & 1.65 & 35 & 2.86 & 1.31 & $\begin{array}{c}1.68^{*} \\
(0.097)\end{array}$ \\
\hline $\begin{array}{l}\text { Helping charities on the } \\
\text { Island }\end{array}$ & 51 & 3.5 & 1.52 & 38 & 2.79 & 1.07 & $\begin{array}{l}2.46^{\star *} \\
(0.016)\end{array}$ \\
\hline
\end{tabular}

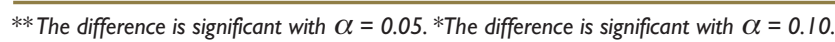

According to Table 4, 58\% of participants in the economics group indicated that banks should charge interest for lending money to economically disadvantaged people whereas the percentage dropped to $27 \%$ in the psychology group. The two groups did not differ in their response to whether to charge interest for commercial purposes. Most participants (in both groups) confirm that interest rates should be limited to a reasonable level. A majority in both groups perceive financial cooperative institutions or companies as better at providing access to funds than current commercial banks.

\section{Table 4. Charging interest by banks}

\begin{tabular}{|c|c|c|c|c|c|c|c|c|}
\hline \multirow[t]{2}{*}{ Classification } & \multicolumn{4}{|c|}{ Economics } & \multicolumn{4}{|c|}{ Psychology } \\
\hline & $T$ & Yes & No & None & $T$ & Yes & No & None \\
\hline $\begin{array}{l}\text { Should banks charge interest for } \\
\text { lending money to economically } \\
\text { disadvantaged people? }\end{array}$ & 51 & 29 & 20 & 1 & 40 & 11 & 22 & 7 \\
\hline $\begin{array}{l}\text { Should the interest rate be limited } \\
\text { to a reasonable level? }\end{array}$ & 51 & 44 & 3 & 4 & 40 & 22 & 7 & 11 \\
\hline $\begin{array}{l}\text { Are the financial cooperative } \\
\text { institutions better at providing } \\
\text { access to funds than current } \\
\text { commercial banks? }\end{array}$ & 51 & 31 & 5 & 15 & 40 & 21 & 10 & 9 \\
\hline
\end{tabular}




\section{Summary and conclusions}

The impact of the financial difficulties that Puerto Rico has been facing since 2007 generates an effect on several dimensions within the economic framework. This article explores the relationship between financial difficulties, banking activities and the social responsibility, as perceived by economics and psychology professionals. A survey was used to collect the data and descriptive statistics were used for the analysis.

The results indicate that neither group perceived banks' social responsibility activities as playing a particularly important role in to Puerto Rico's economy: the average perception of participants in Section B of the survey (see Appendix) is about 3 in a scale 1-5. This indicates that such banking activities are not well perceived by the economics and psychology professionals.

The small size of the sample represents a limitation of this study and a greater sample size would therefore be desirable. Recommendations for further research include expanding the sample to incorporate other professionals, which may reveal differences in their perception of the importance of the role of banking activities in Puerto Rico's growth and economic development. Another proposal arising from the results of this article is to strengthen the influence of financial cooperative institutions on Puerto Rican economic development.

\section{References}

Argenti, P.A., Howell, R.A. and Beck, K.A. (2005). The strategic communication imperative, MIT Sloan Management Review, 46, pp. 30-9.

Barth, J.R., Caprio, J.G. and Levine, R. (2001). The Regulation and Supervision of Banks around the World: A New Database, Brookings-Wharton Papers on Financial Services. Available at http://citeseerx.ist.psu.edu/viewdoc/ download?doi=10.1.1.198.7983\&rep=rep1\&type=pd. $\square$

Barth, J.R., Caprio, J.G. and Levine, R. (2004). Bank Regulation and Supervision: What Works Best? Bank Capital Adequacy Regulation Under the New Basel Accord, Journal of Financial Intermediation, 13(2), pp. 205-248.

Bejou, D., Ennew, C.T. and Palmer, A. (1998). Trust, ethics and relationship satisfaction, International Journal of Bank Marketing, 16(4), pp. 170-175.

Benson, J. (2011). La decada perdida, el precario presente y el incierto futuro, Boletín de Economía, 10(4), Unidad de Investigaciones Económicas, Universidad de Puerto Rico, Recinto de Río Piedras (in Spanish).

Black, S.E. and Strahan, P. (2001). The division of spoils: rent sharing and discrimination in a regulated industry, The American Economic Review, 91(4), pp. 814-831. 
Brown, T.J. and Dacin, P.A. (1997). The company and the product: corporate associations and consumer product responses, Journal of Marketing, 61, pp. 68-84.

Burianova, L. and Paulink, J. (2014). Corporate Social Responsibility in Commercial Banking: A Case Study from the Czech Republic, Journal of Competitiveness, 6(1), pp.50-70, DOI:10.7441/joc.2014.01.04.

- Concilio Latinoamericano de Iglesias (2012). La Declaración de Sao Paulo: Transformación Financiera Internacional para la Economía de la Vida. Available at http://www.claiweb.org/fes/2012/SaoPauloDeclaration_SP.pdf $\square$

Cone, C.L., Feldman, M.A. and DaSilva, A.T. (2003). Causes and Effects, Harvard Business Review, 81(7), pp. 95-101.

Elias, R. (2004). The impact of corporate ethical values on perceptions of earnings management, Managerial Auditing Journal, 19(1), pp. 84-98

Friedman, M. (1962). Capitalismo y Libertad, Rialp, Madrid (in Spanish).

- García de los Salmones, M.d.M., Crespo, A.H. and del Bosque, I.R. (2005). Influence of corporate social responsibility on loyalty and valuation of services, Journal of Business Ethics, 61(4), pp. 369-85.

Gobert, J. and Punch, M. (2003). Rethinking Corporate Crime, Butterworths LexisNexis, London.

Goldstein, R.C. and Nolan, R.L. (2001). Preparing for the privacy police, Harvard Business Review, 79(6), pp. 150-7.

Gore, J.P. (1988). First Fed ad emphasizes community ties, Bank Marketing, 30(3), p. 13.

Guang, L., He, D. and Yang, D. (2006). Auditing, integral approach to quarterly reporting, and cosmetic earnings management, Managerial Auditing Journal, 21(6), pp. 569-581.

Harper, I. and Chan, T. (2003). The Future of Banking: A Global Perspective. In B.E. Gup (Ed.), The Future of Banking, pp. 30-37, Quorum Books, Westport, CT.

Hockerts, K. and Moir, L. (2004). Communicating Corporate Responsibility to Investors: The Changing Role of the Investor Relations function, Journal of Business Ethics, 52(1), pp.85-98.

Irwin, D.A. (1991). Mercantilism as Strategic Trade Policy: The Anglo-Dutch Rivalry for the East India Trade, The Journal of Political Economy, 99(6), pp. 1296-1314.

- La Porta, R., Lopez-De-Silanes, F. and Shleifer, A. (2002). Government Ownership of Banks, Journal of Finance, 57(1), pp. 265-301.

Levi, M. (1987). Regulating Fraud - White-collar Crime and the Criminal Process, Tavistock, London.

Lewis, B.R. and Soureli, M. (2006). The antecedents of consumer loyalty in retail banking, Journal of Consumer Behavior, 5, pp.15-31.

Maignan, I. (2001). Consumers perceptions of Corporate Social Responsibilities: A Cross-Cultural Comparison, Journal of Business Ethics, 30(1), pp. 57-72.

Marx, K. (1887/2010). The process of capitalist production as a whole, CosimoBooks.com.

- Marxuach, S. (2012). La Secuela de las Crisis Financieras. Centro para la Nueva Economía, 10 de abril de 2012. Available at http://grupocne.or/2012/04/10/la-secuela-de-las-crisis-financieras/ש

Mohr, L.A., Webb, D.J. and Harris, K.E. (2001). Do consumers expect companies to be socially responsible? The impact of corporate social responsibility on buying behavior, The Journal of Consumer Affairs, 35(1), pp. 45-72. 
Niu, F. (2006). Corporate governance and the quality of accounting earnings: a Canadian perspective, International Journal of Managerial Finance, 2(4), pp.302-327

Orland, L. (Ed.) (1995). Corporate and White Collar Crime: An Anthology, Anderson, Cincinnati, OH.

Peterson, R.T. and Hermans, C.M. (2004). The communication of social responsibility by US banks, The International Journal of Bank Marketing, 22(3), pp. 199-211.

Pirch, J., Gupta, S. and Grau, S.L. (2007). A framework for understanding corporate social responsibility programs as a continuum: an exploratory study, Journal of Business Ethics, 70(2), pp. 125-40.

Rowlands, I.H., Parker, P. and Scott, D. (2002). Consumer perceptions of green power, The Journal of Consumer Marketing, 19(3), pp. 112-29.

Simpson, G. and Gibbs, C. (Eds.) (2007). Corporate Crime, Ashgate, Aldershort.

Simpson, W. and Kohers, T. (2002). The Link between Corporate Social and Financial Performance Evidence from the Banking Industry, Journal of Business Ethics, 35(2), 97-109.

Smith, N. (2003). Corporate Social Responsibility: Whether or How?, California Management, Review, 45(4), pp. 52-76

Surroca, J., Tribó, J. and Waddock, S. (2010). Corporate Responsibility and Financial Performance: The Role of Intangible Resources, Strategic Management Journal, 31, pp. 147-162. Available at http://www/interscience. wiley.com, DOI:10.102/smj.820

- Tomasic, R. (2000). Corporate crime and its regulation: issues and prospects. In Chappell, D. and Wilson, P. (Eds.), Crime and the Criminal Justice System in Australia: 2000 and Beyond, Butterworths, Sydney, pp. 259-270.

Tomasic, R. (2005). From white-collar crime to corporate crime and beyond: the limits of law and theory. In Chappell, D. and Wilson, P. (Eds.), Issues in Australian Crime and Criminal Justice, LexisNexis, Sydney, pp. 252-267.

Tomasic, R. (2006). The challenge of corporate law enforcement - future directions for corporations law in Australia, University of Western Sydney Law Review, 10, pp. 1-23.

Tomasic, R. (2009). Raising corporate governance standards in response to corporate rescue and insolvency, Corporate Rescue \& Insolvency, 2, pp. 5-9.

Truño, J. and Gual, J. (2006). La Responsabilidad Social Corporativa en la Gestión Empresarial. III Jornada de Pre-Comunicaciones a Congresos de Economía y Administración de Empresas, Autónoma de Barcelona University, Barcelona (in Spanish).

\section{Appendix. Banking activity and social responsibility}

The purpose of this instrument is to explore aspects related to banking activity and social responsibility. Your participation is voluntary. Please select the most appropriate answer according to your perception. You do not need to include your name in the questionnaire. The data will be analyzed at group level and thus no reference will be made to any particular questionnaire. There is no time limit to answer the questionnaire. Please mark $(X)$ under your answer to the corresponding questions 
according to your perception. Please send an e-mail to: jumah@intermetro.edu if you would like to receive a copy of the results.

\section{Section A: Demographic data}

1. Gender $\square$ Female $\square$ Male

2. Field of study $\square$ Psychology $\square$ Economics $\square$ Other

3. Have you completed graduate studies in your study field?
- Yes
$\square$ No
$\square$ In progress

\section{Section B: Banking activity and social responsibility}

Please indicate the level of compliance by the banks in Puerto Rico with respect to

$\square 1$ No compliance

\2 Partial compliance

$\square 3$ Regular compliance

1. Contribution to the economic growth of the Island. $\square$ Normal compliance

$\square$ High compliance

$\square 6$ Don't know

2. Contribution to meeting citizens' needs to obtain residences with low interest.

3. Making sources of finance available to entrepreneurs and SMEs.

4. Support to charitable entities on the Island (eg. Granting donations to community services and nonprofit organizations).

5. The proper use of natural resources and environment (Environmental conservation).

6. Helping charities on the Island. 


\section{Section C: Charging interests}

Should banks charge interest for lending money to economically disadvantaged people?
$\square$ Yes
No
Don't know

Should the interest rate be limited to a reasonable level?
$\square$ Yes
D No
D Don't know

Are the financial cooperative institutions better at providing access to funds than current commercial banks?
- Yes
No
Don't know

Other comments: If you want to add any other point that you consider important in relation to banking activity, please include it here: 